\title{
Hsp27 expression in invasive ductal breast carcinoma
}

\author{
Jedrzej Grzegrzolka ${ }^{1}$, Krzysztof Kurnol ${ }^{1}$, Pawel Piotrow ${ }^{1}$, Bartosz Pula ${ }^{1}$, \\ Christopher Kobierzycki ${ }^{1}$, Aleksandra Piotrowska ${ }^{1}$, Karolina Jablonska ${ }^{1}$, \\ Andrzej Wojnar², Janusz Rys ${ }^{3}$, Piotr Dziegiel ${ }^{1,4,5}$, Marzena Podhorska-Okolow ${ }^{1}$
}

\author{
${ }^{1}$ Department of Histology and Embryology, Medical University, Wroclaw, Poland \\ ${ }^{2}$ Lower Silesian Oncology Center, Wroclaw, Poland \\ ${ }^{3}$ Department of Tumor Pathology, Center of Oncology, Maria Sklodowska-Curie Memorial Institute, \\ Krakow, Poland \\ ${ }^{4}$ Department of Histology and Embryology, University of Medical Sciences, Poznan, Poland \\ ${ }^{5}$ Department of Physiotherapy, Wroclaw University School of Physical Education, Wroclaw, Poland
}

\begin{abstract}
The aim of this study was to determine the intensity of Hsp27 protein expression in fibrocystic breast changes (FC) and invasive ductal breast carcinoma (IDC) and to examine its impact on patients' clinico-pathological characteristics and overall survival. Immunohistochemical reactions were conducted on archival samples of 20 cases of FC and 101 cases of IDC treated in 1999-2002. Nuclear-cytoplasmic Hsp27 expression was observed in $92(92.1 \%)$ of the examined cases of IDC, and all the cases of FC. Significantly higher Hsp27 expression was observed in G2 ( $\mathrm{p}<0.01)$ and G3 cases $(\mathrm{p}<0.0001)$ compared to FC. HER-2 positive cases had higher Hsp27 expression $(\mathrm{p}=0.0153)$, than HER-2 negative cases. Our research showed that Hsp27 could have an impact on tumor malignancy. Moreover, a positive correlation between the expression of Hsp27 and HER-2 positive cases was demonstrated. (Folia Histochemica et Cytobiologica 2012, Vol. 50, No. 4, 527-533)
\end{abstract}

Key words: breast cancer, Hsp27, heat shock protein

\section{Introduction}

Breast cancer is the most frequent female cancer in terms of diagnosis (in Europe, in 2006, 429,900 cases were diagnosed which accounted for $13.5 \%$ of all cancer cases), and one of the three most frequent reasons for mortality from among all types of cancer (131,900 cases) [1]. In the United States in 2010, approximately 207,000 new cases of breast cancer were diagnosed and around 40,000 died from the disease [2]. Although the diagnostic process of breast cancer has been improved, this disease poses a great health problem, because of the lack of reliable molecular

Correspondence address: P. Dziegiel,

Department of Histology and Embryology,

Medical University in Wroclaw,

Chalubinskiego St. 6a, 50-368 Wroclaw, Poland;

tel.: + 487178413 54, fax: + 487178400 82;

e-mail: piotr.dziegiel@am.wroc.pl prognostic factors. However, the development of molecular biology has made it possible to define new potential prognostic factors which may have clinical significance. One of these could be heat shock protein 27 (Hsp27).

Heat shock proteins (Hsps) are highly conserved proteins of which the expression in the cell increases in stress conditions [3]. They have many functional activities such as control of new protein formation, facilitation of transport through the cell's membrane, or repair of stress factor-induced damage [3, 4]. Hsp27 belongs to the family of small Hsps and is expressed in the cytoplasm of a mammal's cells such as myocardial and skeletal muscle cells $[5,6]$. It protects cells from apoptotic factors like cytokines, cytostatic drugs, and ionic radiation by increasing the activation of the $\mathrm{NF}-\kappa \mathrm{B}$ signaling pathway and by influencing the cellular inflammatory response [7, 8]. Increased level of glutathione and modulation of microfilament stability have been found to correlate with a high level of 
Hsp27 expression [9]. Hsp27 has been noted to be overexpressed in breast, ovarian, esophageal, liver and lung cancer [10]. It is significantly associated with estrogen receptor expression in endometrial and female breast carcinoma [10]. High expression of Hsp27 has been found to correlate with resistance to cisplatin, doxorubicin and other anticancer drugs used in breast cancer chemotherapy [11]. The expression of Hsp27 decreases the metastatic potential by increasing the expression of E-cadherin and decreasing the expression of MCAM/MUC18 (MCAM, melanoma cell adhesion molecule) in melanoma cells [12].

In this research, we determine the expression of Hsp27 protein in fibrocystic breast changes (FC) and human invasive ductal breast carcinoma (IDC) using immunohistochemical methods with regards to the patients' clinicopathological data.

\section{Material and methods}

Patients. The study was performed on archival paraffin blocks of 20 cases of FC and 101 cases of IDC from patients treated in the Lower Silesian Oncology Center in Wroclaw during the years 1999-2002. Most of the patients were treated surgically with radical mastectomy or conservative quadrantectomy followed by axillary lymph node resection. In cases of disease stage 3 and above, neoadjuvant therapy was administered. All tissue specimens used in this study were collected before the beginning of the treatment. The clinical and pathological data were obtained from the archives of the Lower Silesian Oncology Center (Table 1). Patients were followed for 52.77 (range 1-118) months.

Immunohistochemistry (IHC). Tissue samples were fixed in $10 \%$ buffered formalin and embedded in paraffin. For immunohistochemical staining, 4- $\mu \mathrm{m}$-thick paraffin sections were cut. Deparaffinization and antigen retrieval were performed in Target Retrieval Solution, $\mathrm{pH} 9\left(97^{\circ} \mathrm{C}, 20 \mathrm{~min}\right)$ and PT Link platform (Dako, Glostrup, Denmark). Then the sections were washed in TBS and stained $\left(4^{\circ} \mathrm{C}\right.$, overnight) with primary rabbit polyclonal antibody directed against p-Hsp27 (sc-101700, Santa Cruz Biotechnology, Inc., Santa Cruz, CA, USA) and with primary antibody against Ki-67 (MIB-1; 1:100; RT, 20 min; Dako) using the Autostainer Link 48 (Dako). Then the slides were washed in TBS and visualization of the studied antibodies was performed using the EnVision FLEX system (Dako) according to the manufacturer's instructions. All slides were counterstained with Mayer's hematoxylin (Dako).

For all sections, a staining for estrogen receptor (ER), progesterone receptor (PR) and human epidermal growth factor receptor-2 (HER-2) was performed as previously described [13]. Briefly, 4- $\mu \mathrm{m}$-thick paraffin sections were cut, dewaxed, gradually rehydrated and boiled in Antigen
Table 1. Patient and tumor characteristics

\begin{tabular}{|c|c|c|}
\hline \multicolumn{2}{|c|}{ Mean age in years (range) } & $57 \pm 11(35-83)$ \\
\hline Parameters & Number & $\%$ \\
\hline Age & & \\
\hline$\leq 50$ & 31 & 30.09 \\
\hline$>50$ & 70 & 69.91 \\
\hline Menopausal status & & \\
\hline Pre & 68 & 67.33 \\
\hline Post & 33 & 32.67 \\
\hline Grade of malignancy & & \\
\hline G1 & 9 & 8.91 \\
\hline G2 & 52 & 51.49 \\
\hline G3 & 40 & 39.60 \\
\hline pT & & \\
\hline $\mathrm{Tl}$ & 55 & 54.46 \\
\hline $\mathrm{T} 2$ & 35 & 34.65 \\
\hline $\mathrm{T} 3$ & 8 & 7.92 \\
\hline $\mathrm{T} 4$ & 3 & 2.97 \\
\hline $\mathrm{pN}$ & & \\
\hline pNO & 52 & 51.49 \\
\hline $\mathrm{pN} 1, \mathrm{pN} 2, \mathrm{pN} 3$ & 46 & 45.54 \\
\hline $\mathrm{pNx}$ & 3 & 2.97 \\
\hline ER & & \\
\hline Positive & 81 & 80.20 \\
\hline Negative & 20 & 19.80 \\
\hline PR & & \\
\hline Positive & 70 & 69.03 \\
\hline Negative & 31 & 31.97 \\
\hline HER-2 by IHC & & \\
\hline Positive & 16 & 15.84 \\
\hline Negative & 85 & 84.16 \\
\hline Ki-67 & & \\
\hline$<25 \%$ & 72 & 71.29 \\
\hline$\geq 25 \%$ & 29 & 28.71 \\
\hline
\end{tabular}

Retrieval Solution ( $\mathrm{pH}$ 6; Dako). The activity of endogenous peroxidase was blocked with $3 \% \mathrm{H}_{2} \mathrm{O}_{2}$. Slides were then incubated overnight at $4^{\circ} \mathrm{C}$ with primary antibodies (clone 1D5 at 1:100 dilution for ER, clone PgR 636 at 1:100 dilution for PR; both Dako). Following incubation with secondary biotinylated antibodies (Biotinylated Link), reactions with the streptavidin-biotinylated peroxidase complex (LSAB+ System-HRP; Dako) were performed. The peroxidase substrate of 3,3'-diaminobenzidine (DAB+ Chromogen) was used as a chromogen. All the sections were counterstained with hematoxylin. Expression of HER-2 was examined using a HercepTest ${ }^{\mathrm{TM}}$ (Dako) kit, according to the procedure recommended by the manufacturer. 
Table 2. Remmele scale: percentage of positive cells (A) and the intensity of color reaction (B). The final score represents the product of these parameters $(\mathrm{A} \times \mathrm{B})$

\begin{tabular}{|c|c|}
\hline A & B \\
\hline 0 pts - no cells with positive reaction & 0 pts - no staining \\
\hline $1 \mathrm{pt}-$ to $10 \%$ cells with positive reaction & $1 \mathrm{pt}-$ low intensity of staining \\
\hline $2 \mathrm{pts}-11-50 \%$ cells with positive reaction & $2 \mathrm{pts}-$ moderate intensity of staining \\
\hline $3 \mathrm{pts}-51-80 \%$ cells with positive reaction - intense staining \\
\hline $4 \mathrm{pts}->80 \%$ cells with positive reaction & \\
\hline
\end{tabular}
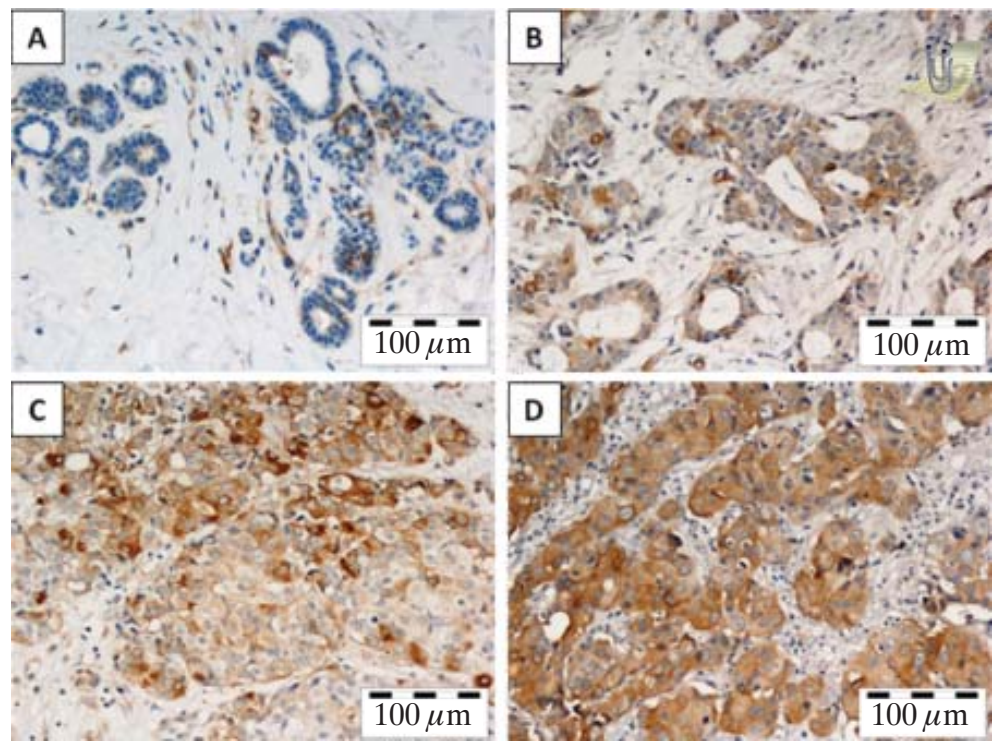

Figure 1. Hsp27 expression in breast duct cells (A) and IDC cases of G1 (B), G2 (C) and G3 (D). Magnification $\times 200$

Histopathological examination and analysis of IHC. H\&E sections were evaluated by two independent pathologists (WA, DP) to confirm the diagnosis and assess the grade of malignancy and presence of necrosis. Sections were regarded as positive when the extent of the necrotic area was greater than $10 \%$.

All immunostainings were evaluated by two pathologists using a BX-41 light microscope (Olympus, Tokyo, Japan). For the Hsp27 evaluation, immunoreactive scale of Remmele was applied [14] (Table 2). The Ki-67 antigen was evaluated according to tumor cell positivity and encoded as follows: 0 ( $0 \%$ cells stained), 1 (1-10\% cells stained), 2 (11$-25 \%$ cells stained), 3 (26-50\% cells stained), and 4 (51$-100 \%$ cells stained).

PR and ER analysis was evaluated according to the percentage of positive cancer cells in whole tissue sections on a four-grade scale as follows: $0 \%-0,1-10 \%-1,11-50 \%$ - 2; and 51-100\% - 3. Sections scoring 1 and above were regarded as positive. HER-2 sections scoring 3 were regarded as positive [15].
Statistical analysis. Statistical analysis was performed by Prism 5.0 (GraphPad, CA, USA). Correlations between expression of Hsp27 and Ki-67 were analyzed by Spearman's correlation test. The correlations between expression of Hsp27 and clinicopathological parameters were analyzed by: Kruskal-Wallis, Mann-Whitney tests (tumor grade) and Fischer exact test. The Mantel Cox test was used to compare the differences in patient survival. Results were considered statistically significant with $\mathrm{p}<0.05$ in all analyses.

\section{Results}

Hsp27 cytoplasmic expression was noted in breast duct cells of FC (2.50 \pm 0.76$)$ and in myofibroblasts of breast acini and vessels of breast stroma (Figure 1A). Hsp27 expression was noted in 92 (92.1\%) examined cases of IDC (4.97 \pm 3.10 ; Figures 1B-D). In some cases, additional expression was observed in cancer cell nuclei. Significant difference in Hsp27 
A

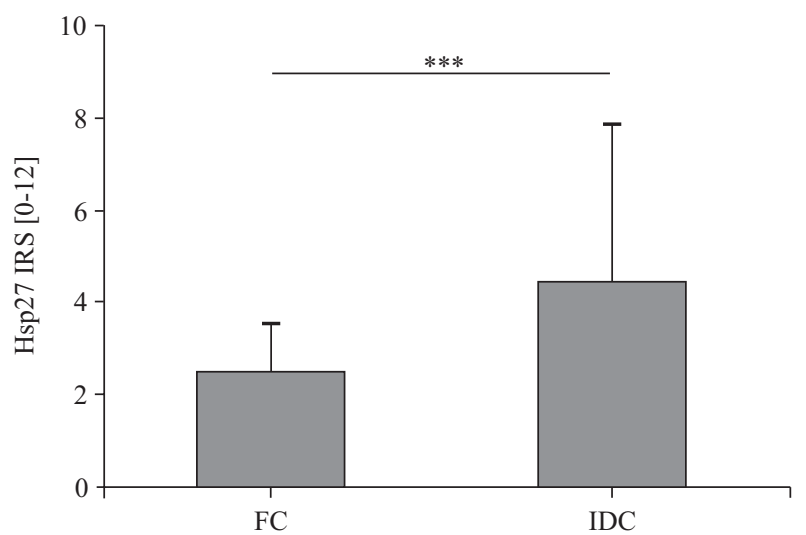

B

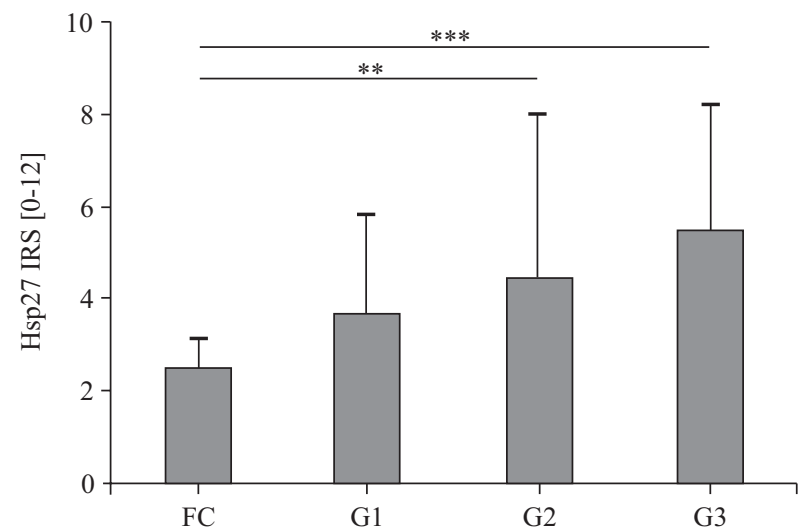

Figure 2. Statistical analysis revealed significantly higher Hsp27 expression in IDC compared to breast duct cells of FC $(\mathrm{p}<0.0001)(\mathbf{A})$. When the relationship between its expression in mastopathies and in different malignancy grades was analyzed, significantly higher Hsp27 expression was observed in G2 (p = 0.0047) and G3 cases $(\mathrm{p}<0.0001)(\mathbf{B})$.

$* * \mathrm{p}<0.005, * * * \mathrm{p}<0.0001$

expression was observed between FC and IDC (Figure 2A). Moreover, when this relationship was analyzed regarding the grade of malignancy, a positive trend of Hsp27 expression was observed in IDC, although it was not significant (Figure 2B). Almost significant higher expression of Hsp27 was noted in G3 cancers compared to cases of G1 $(\mathrm{p}=0.0524)$.

Hsp27 expression was associated with HER-2 positivity ( $\mathrm{p}=0.0153)$, and cases which were HER-2 positive tended to have higher levels of Hsp27 $(p=0.072$; Table 3, Figure 3). Our study revealed no correlation of Hsp27 expression with tumor cell proliferation measured by the expression of Ki-67 antigen. Univariate analysis showed no impact of Hsp27 on patients' clinical outcome and event free survival.

\section{Discussion}

The expression of Hsp27 in malignant cells has been observed in many studies. To date, its expression has been detected in breast, endometrial, ovarian, lung cancer, melanoma and others [10, 16-24]. In ovarian, prostate and gastric cancer, a high level of Hsp27 expression was associated with a poor clinical outcome [10]. Some studies have shown that Hsp27 is not a useful prognostic factor, and therefore on the basis of results obtained by others we analyzed its expression in a different group of patients with IDC [25].

Our study showed significant differences between the expression of Hsp27 in the group of IDC cases compared to FC cases. Although our study did not show any statistical difference between Hsp27 expression in cases of FC and G1 cases of IDC, significantly higher Hsp27 expression was noted in FC in relation to G2 and G3 IDC cases. Hsp27 expression was almost significantly higher in G3 than in G1 cases. There was also a trend of higher expression of Hsp27 in G2 compared to G1. This indicates that Hsp27 could influence IDC malignancy. However, our results did not reveal any positive correlation between level of Hsp27 and Ki-67.

These results conflict with recently published data which demonstrated that Hsp-27 expression was inversely correlated with the grade of malignancy of invasive ductal breast cancer [26]. In astrocytoma and hepatocellular cancer, Hsp27 expression was positively correlated with grade of malignancy [27-29]. However, no significant correlation between grade of malignancy and level of Hsp27 expression in ovarian cancer, squamous cell carcinoma of the tongue and esophagus, bladder carcinoma or gastric cancer was observed [30-32]. That suggests that the expression of Hsp27 has a heterogeneous character and is specific for the type of tumor; the role of this protein in carcinogenesis remains unclear.

Hsp27, which is also known as a cytoplasmic estrogen receptor associated protein (p29), selectively binds GTP and to a lesser extent ATP and plays a role in the estrogen response intracellular pathways $[33,34]$. Our study did not show any correlation between Hsp27 expression and the expression of ER and PR. Our data is in agreement with similar results obtained by others [26,35-38], although the study by Ciocca et al. described a positive correlation between Hsp27 and ER [16]. This discrepancy needs further investigation.

We have also shown that Hsp27 expression correlates with HER-2 expression. Similar results were 
Table 3. Correlations between Hsp27 expression and clinico-pathological characteristics of studied patients. Significant $\mathrm{p}$ values are given in bold

\begin{tabular}{|c|c|c|c|c|}
\hline \multirow[t]{2}{*}{ Characteristics } & \multirow[t]{2}{*}{ Number $(\%)$} & \multicolumn{2}{|c|}{ Hsp27 expression (number (\%) } & \multirow[t]{2}{*}{$\mathbf{p}$} \\
\hline & & IRS 0-4 & IRS 6-12 & \\
\hline $\begin{array}{l}\text { Age } \\
\qquad 50 \\
>50\end{array}$ & $\begin{array}{l}31(30.09) \\
70(69.91)\end{array}$ & $\begin{array}{c}13(41.93) \\
41(58.6)\end{array}$ & $\begin{array}{c}18(58.07) \\
29(41.4)\end{array}$ & 0.1358 \\
\hline $\begin{array}{l}\text { Menopausal status } \\
\text { Pre } \\
\text { Post }\end{array}$ & $\begin{array}{l}33(32.67) \\
68(67.33)\end{array}$ & $\begin{array}{l}13(39.39) \\
41(60.29)\end{array}$ & $\begin{array}{l}20(60.61) \\
27(39.71)\end{array}$ & 0.0587 \\
\hline $\begin{array}{l}\text { Tumor size } \\
\text { pT1 } \\
\text { pT2-4 }\end{array}$ & $\begin{array}{l}55(54.45) \\
46(45.55)\end{array}$ & $\begin{array}{l}29(52.72) \\
25(54.35)\end{array}$ & $\begin{array}{l}26(47.28) \\
21(45.65)\end{array}$ & 0.8437 \\
\hline $\begin{array}{l}\text { Lymph nodes } \\
\qquad \text { N0 } \\
\text { N1-3 }\end{array}$ & $\begin{array}{l}52(51.49) \\
46(45.54)\end{array}$ & $\begin{array}{l}30(57.69) \\
22(47.82)\end{array}$ & $\begin{array}{l}22(42.31) \\
24(52.18)\end{array}$ & 0.4178 \\
\hline $\begin{array}{l}\text { ER } \\
\text { Positive } \\
\text { Negative }\end{array}$ & $\begin{array}{l}81(80.20) \\
20(19.80)\end{array}$ & $\begin{array}{l}43(53.08) \\
11(55.00)\end{array}$ & $\begin{array}{c}38(46.92) \\
9(45.00)\end{array}$ & 1.0000 \\
\hline $\begin{array}{l}\text { PR } \\
\text { Positive } \\
\text { Negative }\end{array}$ & $\begin{array}{l}70(69.03) \\
31(31.97)\end{array}$ & $\begin{array}{l}38(54.28) \\
16(51.61)\end{array}$ & $\begin{array}{l}32(45.72) \\
15(48.39)\end{array}$ & 0.8317 \\
\hline $\begin{array}{l}\text { HER-2 } \\
\text { Positive } \\
\text { Negative }\end{array}$ & $\begin{array}{l}16(15.84) \\
85(84.16)\end{array}$ & $\begin{array}{c}4(25.00) \\
50(58.82)\end{array}$ & $\begin{array}{l}12(75.00) \\
35(41.18)\end{array}$ & 0.0153 \\
\hline
\end{tabular}

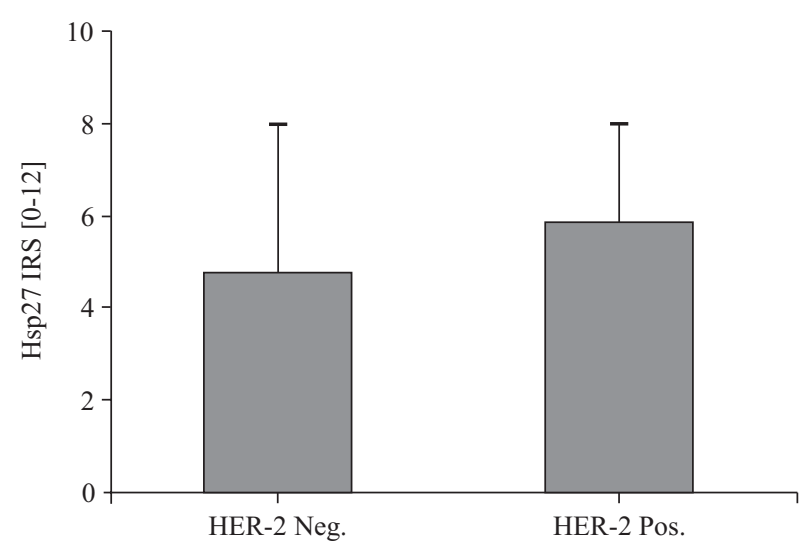

Figure 3. Intensity of Hsp27 expression in HER-2 negative and positive cases of IDC

demonstrated by Liebhardt et al. [39]. The study by Meng et al. revealed that heat-shock transcription factor HSF1 has an important role in cellular transformation induced by HER-2 [40]. Cells with knockdown of HSF1 presented lower foci formation and reduced tumor growth when xenografted to mice. In HER-2 positive breast cancer cell lines, loss of HSF1 expression was associated with increase of p21 and decrease of cells survival, Hsp27 and Hsp72 expression [40, 41]. The results obtained in this study are in agreement with the results obtained by Meng et al. in their research. Kang et al. demonstrated in breast cancer cells that the high expression of Hsp27 increases HER-2 stability, by the formation of a HER-2-Hsp27 complex therefore reducing the susceptibility to Herceptin treatment [41]. Cardoso et al. focused their work on the description of various markers in breast cancer and metastatic lymph nodes, including HER-2 and Hsp27, but the authors did not analyze the relationship between those two proteins [42]. Their results showed that Hsp27 was present in 44\% of the examined primary tumors (compared to our $92.1 \%$ ). These differences might be the result of using a different cut-off for the definition of positivity [42]. Moreover, in our study, all cases of diffuse cystic mastopathies were characterized by the expression of Hsp27.

Our results showed that Hsp27 may be involved in the early steps of carcinogenesis. Although our results did not demonstrate any correlation between Hsp27 expression and clinico-pathological factors, the correlation of Hsp27 and HER-2 may be an interesting point of research in determining carcinogenesis 
and progression of IDC. Moreover, a significantly higher Hsp27 expression in less differentiated cases of IDC may be indicative of its role in the early steps of carcinogenesis.

\section{Acknowledgments}

This research was supported by Wroclaw Research Center EIT+ under the 'Biotechnologies and advanced medical technologies' project, BioMed (POIG.01.01.02-02-003/08) financed from the European Regional Development Fund (Operational Program Innovative Economy, 1.1.2).

\section{References}

1 Ferlay J, Autier P, Boniol M, Heanue M, Colombet M, Boyle P. Estimates of the cancer incidence and mortality in Europe in 2006. Ann Oncol. 2007;18:581-592.

2 Jemal A, Siegel R, Xu J, Ward E. Cancer Statistics, 2010. CA Cancer J Clin. 2010;60:277-300.

3 De Maio A. Heat shock proteins: facts, thoughts, and dreams. Shock. 1999;11:1-12.

4 Morimoto RI, Kline MP, Bimston DN, Cotto JJ. The heatshock response: regulation and function of heat-shock proteins and molecular chaperones. Essays Biochem. 1997;32:1729.

5 Golenhofen N, Perng MD, Quinlan RA, Drenckhahn D. Comparison of the small heat shock proteins alphaB-crystallin, MKBP, HSP25, HSP20, and cvHSP in heart and skeletal muscle. Histochem Cell Biol. 2004;122:415-425.

6 Jolly C, Morimoto RI. Role of the heat shock response and molecular chaperones in oncogenesis and cell death. $J$ Natl Cancer Inst. 2000;92:1564-1572.

7 Concannon CG, Gorman AM, Samali A. On the role of Hsp27 in regulating apoptosis. Apoptosis. 2003;8:61-70.

8 Parcellier A, Schmitt E, Gurbuxani et al. HSP27 is a ubiquitin-binding protein involved in I-kappaBalpha proteasomal degradation. Mol Cell Biol. 2003;23:5790-5802.

9 Arrigo AP. Small stress proteins: chaperones that act as regulators of intracellular redox state and programmed cell death. Biol Chem. 1998;379:19-26.

10 Ciocca DR, Calderwood SK. Heat shock proteins in cancer: diagnostic, prognostic, predictive, and treatment implications. Cell Stress Chaperones. 2005;10:86-103.

11 Shi P, Wang MM, Jiang LY, Liu HT, Sun JZ. Paclitaxel-doxorubicin sequence is more effective in breast cancer cells with heat shock protein 27 overexpression. Chin Med J. 2008;121:1975-1979.

12 Aldrian S, Kindas-Mugge I, Trautinger F et al. Overexpression of Hsp27 in a Human Melanoma Cell Line: Regulation of E-Cadherin, MUC18/MCAM, and Plasminogen Activator (PA) System. Cell Stress \& Chaperones. 2003;8:249-257.

13 Gomulkiewicz A, Podhorska-Okolow M, Szulc R. Correlation between metallothionein (MT) expression and selected prognostic factors in ductal breast cancers. Folia Histochem Cytobiol. 2010;48:242-248.

14 Remmele W, Stegner HE. Recommendation for uniform definition of an immunoreactive Score (IRS) for immunohistochemicalestrogen receptor detection (ER-ICA) in breast cancer. Pathologe. 1987;8:138-140.

15 Wolff AC, Hammond ME, Schwartz JN et al. Wheeler TM and Hayes DF; American Society of Clinical Oncology/Col- lege of American Pathologists: American Society of Clinical Oncology/College of American Pathologists guideline recommendations for human epidermal growth factor receptor 2 testing in breast cancer. Arch Pathol Lab Med. 2007;131:18-43.

16 Ciocca DR, Stati AO, Amprino de Castro MM. Colocalization of estrogen and progesterone receptors with an estrogen-regulated heat shock protein in paraffin sections of human breast and endometrial cancer tissue. Breast Cancer Res Treat. 1990;16:243-251.

17 Muńoz de Toro MM, Luque EH. Lack of relationship between the expression of hsp27 heat shock estrogen receptorassociated protein and estrogen receptor or progesterone receptor status in male breast carcinoma. J Steroid Bioc Mol Biol. 1997;60:277-284.

18 Vargas-Roig LM, Fanelli MA, López LA et al. Heat shock proteins and cell proliferation in human breast cancer biopsy samples. Cancer Detect Prev. 1997;21:441-451.

19 Ciocca DR, Puy LA, Edwards DP, Adams DJ, McGuire WL. The presence of an estrogen-regulated protein detected by monoclonal antibody in abnormal human endometrium.J Clin Endocrinol Metab. 1985;60:137-143.

20 Ciocca DR, Puy LA, Fasoli LC. Study of estrogen receptor, progesterone receptor, and the estrogen-regulated Mr 24,000 protein in patients with carcinomas of the endometrium and cervix. Cancer Res. 1989;49:4298-4304.

21 Navarro D, Cabrera JJ, León L, Chirino R et al. Endometrial stromal sarcoma expression of estrogen receptors, progesterone receptors and estrogen-induced srp27 (24K) suggests hormone responsiveness. J Steroid Biochem Mol Biol. 1992;41:589-596.

22 Langdon SP, Rabiasz GJ, Hirst GL et al. Expression of the heat shock protein HSP27 in human ovarian cancer. Clin Cancer Res. 1995;1:1603-1609.

23 Małusecka E, Zborek A, Krzyzowska-Gruca S, Krawczyk Z. Expression of heat shock proteins HSP70 and HSP27 in primary non-small cell lung carcinomas. An immunohistochemical study. Anticancer Res. 2001;21:1015-1021.

24 Missotten GS, Journée-de Korver JG, de Wolff-Rouendaal D, Keunen JE, Schlingemann RO, Jager MJ. Heat shock protein expression in the eye and in uveal melanoma. Invest Ophthalmol Vis Sci. 2003;44:3059-3065.

25 Oesterreich S, Hilsenbeck SG, Ciocca DR et al. The small heat shock protein HSP27 is not an independent prognostic marker in axillary lymph node-negative breast cancer patients. Clin Cancer Res. 1996;2:1199-1206.

26 Love S, King RJ. A 27 kDa heat shock protein that has anomalous prognostic powers in early and advanced breast cancer. Br J Cancer. 1994;69:743-748.

27 Assimakopoulou M, Sotiropoulou-Bonikou G, Maraziotis T, Varakis I. Prognostic significance of Hsp-27 in astrocytic brain tumors: an immunohistochemical study. Anticancer Res. 1997; 17:2677-2682.

28 Khalid H, Tsutsumi K, Yamashita H, Kishikawa M, Yasunaga A, Shibata S. Expression of the small heat shock protein (hsp) 27 in human astrocytomas correlates with histologic grades and tumor growth fractions. Cell Mol Neurobiol. 1995; 15:257-268.

29 King KL, Li AF, Chau GY et al. Prognostic significance of heat shock protein-27 expression in hepatocellular carcinoma and its relation to histologic grading and survival. Cancer. 2000;88:2464-2470.

30 Ito T, Kawabe R, Kurasono Y, Hara M, Kitamura H, Fujita $\mathrm{K}$, Kanisawa M. Expression of heat shock proteins in squamous cell carcinoma of the tongue: an immunohistochemical study. J Oral Pathol Med. 1998;27:18-22. 
31 Kawanishi K, Shiozaki H, Doki Y et al. Prognostic significance of heat shock proteins 27 and 70 in patients with squamous cell carcinoma of the esophagus. Cancer. 1999;85:1649-1657.

32 Giaginis C, Daskalopoulou SS, Vgenopoulou S, Sfiniadakis I, Kouraklis G, Theocharis SE. Heat Shock Protein-27, -60 and -90 expression in gastric cancer: association with clinicopathological variables and patient survival. BMC Gastroenterol. 2009;9:14.

33 Ciocca DR, Luque EH. Immunological evidence for the identity between the hsp27 estrogen-regulated heat shock protein and the p29 estrogen receptor-associated protein in breast and endometrial cancer. Breast Cancer Res Treat. 1991;20:33-42.

34 Coffer AI, King RJ. Characterization of p29, an estrogenreceptor associated tumor marker. J Steroid Biochem. 1988;31:745-750.

35 Takahashi S, Narimatsu E, Asanuma $\mathrm{H}$ et al. Immunohistochemical detection of estrogen receptor in invasive human breast cancer: correlation with heat shock proteins, pS2 and oncogene products. Oncology. 1995;52:371-375.

36 Ioachim E, Tsanou E, Briasoulis E et al. Clinicopathological study of the expression of hsp27, pS2, cathepsin D and metallothionein in primary invasive breast cancer. Breast. 2003;12:111-119.
37 Mlynarczyk-Liszka J, Maksymiuk B, Ponikiewska D. HSP27 diagnostic utility in the fine needle aspirate of breast. Correlation with progesterone and estrogen receptors. Neoplasma. 2009;56:357-360.

38 Hurlimann J, Gebhard S, Gomez F. Oestrogen receptor, progesterone receptor, pS2, ERD5, HSP27 and cathepsin D in invasive ductal breast carcinomas. Histopathology. 1993;23:239-248.

39 Liebhardt S, Ditsch N, Nieuwland R et al. CEA-, Her2/neu-, BCRP- and Hsp27-positive microparticles in breast cancer patients. Anticancer Res. 2010;30:1707-1712.

40 Meng L, Gabai VL, Sherman MY. Heat-shock transcription factor HSF1 has a critical role in human epidermal growth factor receptor-2-induced cellular transformation and tumorigenesis. Oncogene. 2010;29:5204-5213.

41 Kang SH, Kang KW, Kim KH et al. Upregulated HSP27 in human breast cancer cells reduces Herceptin susceptibility by increasing Her2 protein stability. BMC Cancer. 2008;8:286.

42 Cardoso F, Di Leo A, Larsimont D et al. Evaluation of HER2, p53, bcl-2, topoisomerase II-alpha, heat shock proteins 27 and 70 in primary breast cancer and metastatic ipsilateral axillary lymph nodes. Ann Oncol. 2001;12:615-620.

Submitted: 2 July, 2012 Accepted after reviews: 11 November, 2012 